\title{
Confidence in the police: balancing public image with community safety - a comparative review of the literature
}

Examining the evolution of British and Australian policing, this comparative review of the literature considers the impact of community legitimacy derived from early concepts of policing by consent against contemporary policing challenges. Using the August 2011 disorder in Britain as a lens, this paper considers whether, in striving to maintain community confidence, undue emphasis is placed on the police's public image at the expense of community safety. Examining the path of policing reform, the impact of bureaucracy on policing and the evolving debate surrounding police performance, this review suggests that, while largely delivering on the ideal of an ethical and strong police force, a preoccupation with self-image may in fact result in tarnishing the very thing British and Australian police forces strive to achieve - their standing with the public. This paper advocates for a more realistic goal of gaining public respect rather than affection in order to achieve the difficult balance between maintaining trust and respect as an approachable, ethical entity providing firm, confident policing in this ever-evolving, modern society.

Keywords: policing reform; Britain; Australia; policing performance; policing by consent; police-public relations 


\section{Introduction}

Various scholarly accounts of the history of British policing describe the underpinning philosophy of its development: that the police and public are but one community, which in turn gives its 'consent' to be policed (Reith 1956, O'Brien 1972, Williams and Harris 2008). This comparative review explores whether, in striving to maintain the community's confidence, undue emphasis is placed by police on concepts of image through public relations activity, rather than service delivery. It also examines whether police are at risk of neglecting the 'public assurance' component of their informal societal contract to maintain community safety.

In Britain, Sir Robert Peel's 1829 legislation established London's

Metropolitan Police and later that year, joint founding Commissioners Charles Rowan and Richard Mayne drafted nine 'Principles of Policing' for the guidance of officers (Reith 1956). These incorporate themes of police and community co-operation and policing by the community's consent, a concept commonly held to be crucial to the success of western democratic policing (Jones et al. 1996, Jackson 2010). Modern police practices strive to maintain a model of community co-operation (Innes et al. 2007, Morgan and Newburn 1997).

In the 180 years since Rowan and Mayne's seminal vision of policing, much has changed within societies using this as a concept of social control. The rapid liberalisation of western society from the 1960s, changes in standards of behaviour and shifting public mores on a range of issues are some of the challenges facing modern policing (Marenin 1996, Walker and Richards 1996). As a result, much reform in policing has occurred since the 1970s (Woodcock 1991, Etter 1993, Ryan 1996). Throughout, police strive to maintain a positive public image in a 'hearts and minds' battle to reassure society and maintain its 'consent' (Innes et al. 2007, p. 9). 


\section{Approach}

This study provides a comparative review of the literature on specific issues identified for discussion. It describes how community legitimacy is given to modern policing through the early British concepts of policing by consent. The linkages between British and Australian policing models, provided by shared history and culture are briefly explored in a comparative sense. This study acknowledges that the challenges facing police from government directives to do 'more with less' are compounded by tensions surrounding community needs and expectations. Increased media coverage, communication technology and public awareness have combined to ensure that expectations of the police have never been higher, nor their role more complex. With this in mind, three contemporary issues concerning policing are examined in depth:

(1) the path of police reform;

(2) the impact of bureaucracy on policing; and

(3) the evolving debate on police performance.

A comparative review of these issues from either the British and Australian policing perspective identified that many of the challenges are relevant to both policing jurisdictions. However, discussion of the public debate on police performance is approached from a new frame of reference rather than the traditional issues of police misconduct or malfeasance: the August 2011 disorder in Britain, the ensuing debate about police tactics and the ramifications for British and Australian policing.

\section{Discussion}

\section{Origins of British policing}

By examining the development of policing in Britain, we can conceptualise a 
developmental path of policing both there and in Australia. A useful point from which to commence this analysis is Rowan and Mayne's 1829 nine 'Principles of Policing', often referred to in historical accounts of the development of western democratic policing (Critchley 1967, 1977, Uildirks and Van Reenen 2004). The principles encompass notions of police/public connectedness as one society and it is strikingly apparent that all contain a strong theme of police and public co-operation.

Reith's (1956) still relevant account of Britain's policing development noted that Rowan and Mayne's concept of a police force was unique in history and throughout the world because it derived power not from fear but almost exclusively from public co-operation with the police. These concepts are seen as strong foundations in the development of a democratic policing model and remain highly influential in the western world today (Williams and Harris 2008).

\section{The power of legitimacy}

This policing philosophy survived and flourished as the police forces of Britain and Australia developed and evolved in the following 180 years. Beetham (1991) contends that the intertwining of police and the public as outlined in the principles gives legitimacy to the British policing model, providing it with a high degree of quasi-moral authority. People confer legitimacy on institutions not simply because the latter adhere to standards of good behaviour, but also because they regard them as normative and ethical frameworks (Beetham 1991). A similar view is supported by the American study by Tyler and Fagan (2008).

Jackson et al. (2012) examined why a sense of moral alignment between police and people is such an important component of police legitimacy in Britain. They noted that this legitimacy can have a powerful impact on police-public 
relations. If people base legitimacy on common moral values, then demonstrations of shared purpose will be key; if most people are concerned about justice and morality, then legitimacy is given a sounder normative basis (Jackson et al. 2012).

\section{Historical and cultural parallels in policing}

The similarities between British and Australian policing structures, practices and law are self-evident. This is to be expected, given the development of Australian policing from the British model (Enders 2001). These commonalities are highly visible, everywhere from police ranks, uniform, insignia, terminology, procedural instructions, mode of operations and statute law enforced by police. With similarities in history, societal culture, system of government and common threats faced, British and Australian policing practices are inextricably and closely linked (Senior 1997).

Britain's police structure has evolved in line with its central and local government model and geographic forces based on county and municipal borders in England and Wales (Scotland having its own arrangements). Historically, each has been led by a Chief Constable who under statute had authority of 'direction and control' of the force. Until 2012, Chief Constables were directly accountable to the Home Secretary for national efficiency and effectiveness, and to local democratic oversight via a police consultative committee (ACPO 2012).

However, a seismic change has occurred in police leadership and accountability protocols from late 2012, marking a major departure from the traditions of the past. In November 2012, 41 police and crime commissioners (PCCs) were elected across England and Wales to give the public a say about cutting crime. In London the Mayor of London has the powers of a PCC. The 
power of the new PCCs are far reaching within their local area; they include holding the chief constable to account for policing, including appointing and, where necessary, dismissing them, setting and updating a police and crime plan, setting the force budget and regularly engaging with the public. The PCC is directly accountable to the public for the performance of the police service in their area. As Gilmore (2012) noted, the PCC for each police force is directly elected by the public. This presents a looming challenge to the doctrine central to British models of policing accountability, whereby Chief Constables had direct and exclusive control of policing within their force without political interference. It is as yet unclear how much operational influence the PCCs will have on their police force and by consequence, how much, if any, the police will be politicised through these major changes in accountability and control.

In contrast, Australia has in effect nine legal systems: eight state and territory systems and one federal system. All Australia states as well as the Northern Territory have their own police forces that deal with crimes under state or territory laws. The Australian Federal Police investigate offences against federal laws, including drug trafficking, illegal immigration, crimes against national security and the environment (AIC 2012). Enders (2001) notes that Australia has a less centralised organisational structure than that of Britain's. However, the small number of police agencies in Australia means that policy communication between its leadership is relatively easy compared to the British model.

\section{Policing a changing world with finite resources}

It can be argued that any discussion of modern policing challenges should start with an acknowledgement of the inherent and constant strain between finite resources, 
operating budgets and the expanding roles and responsibilities of police in a modern, evolving society (Rogers and Gravelle 2012). Technological, social and demographic change (Bird 1992) and the phenomenon of globalisation (Clarke and Knake 2010) are key generators of new challenges for policing. They are also important factors driving police away from their founding principles, thereby weakening connections with the public (Bayley and Nixon 2010).

As with many government service industries, police must now do more with less (Etter 1993, Fleming and Graboski 2009). Thus, a juggling of resources and priorities is ever present, bringing inevitable tensions and the inability to 'deliver' in certain areas at certain times (Batts et al. 2012). Palmer (1995) observed that these challenges are continual and are only likely to increase. The police must now be all things to all people (Jinks 1990). It is posited that these very real resource constraints on police are a reasonable and pragmatic starting point from which to commence this comparative review.

\section{The road to police reform}

Following a long period of stability, reflecting little change in the wider social setting, the 1960s set in train moves to modernise police practices. Consequently, the 1970s and 1980s brought various drivers of police reform: misconduct scandals; incidents of poor performance; ethnic, cultural and demographic changes in Britain and later Australia. Additionally, a push developed from within the police themselves to 'professionalise' and provide a better image to the public (Palmer 1995, Stone and Travis 2011, Sklansky 2011). An increased level of sophistication within society, combined with higher awareness about civil rights has lead to greater accountability and interest in what the police do and how they do it (Patton 1992). An increasingly 
consumerist society means that people expect to be regarded as 'customers' and treated with a deference almost akin to that offered in a retail transaction (Halpren 2010; Rogers \& Martin 2007). Finally, technological change in the form of an information explosion has been the catalyst for transforming society and thus its policing needs (Batt et al. 2012).

Much of this reform has been in response to changes in society, but some observers have questioned whether reform has become part of an ongoing cycle - in other words, the 'new normal'. Fleming and Rhodes (2004b) note that for police services, organisational reform is no longer an event but a way of life. Reform has become cyclical; as each new Commissioner of Police takes the reigns, he or she is eager to stamp their mark through new programs and initiatives. Reform in policing is often linked with new models of managerialism, bringing a new order to British policing (Cope et al. 1997).

New management techniques were drawn from the private sector in the $1980 \mathrm{~s}$ to restructure public sector agencies along broadly corporate lines (Vickers and Kouzmin 2001, Terpstra and Trommel 2009). Performance management regimes, accountability mechanisms, external civilian review bodies and more stringent budget reporting are just some of the factors placing major additional bureaucratic burdens on police, so much so that administrative reform has become a continuing activity (Fleming and Rhodes 2004a).

Bayley (1994), Prenzler and Ransley (2002) and Fleming and Lafferty (2000) describe how the major agendas for police reform in Australia have been driven by demands for efficiency, effectiveness, concerns about police-community relationships and police performance. By contrast, Fleming and Rhodes (2004a) note that industrial strife and public disorder in Britain provided the impetus for the reforms of the 1980s, 
principal amongst these being the findings of Lord Scarman (1986) into the Brixton riots of the early 1980s. Sir Patrick Sheehy (1993), in a report concerning police performance found that structural and organisational reforms of the police have been driven by managerialist agendas of operational effectiveness, efficiency and accountability.

There is no doubt that police have historically been resistant to change. The move in the early 1990s to remake police organisations as corporate entities was resisted vigorously in Australia by senior police officers, rank and file police and their unions (Fleming and Lafferty 2000). Similarly, the British Government's white paper on police reform in 1992 created an unprecedented wave of resistance from police officers at every level (Reiner 1993).

Research in this millennium suggests that the police remain reluctant to embrace change. Davies and Thomas (2003 p. 682-3) claim that police organisations are resistant to change because of a deeply entrenched and pervasive occupational culture. Fleming and Rhodes (2004b) note that most accounts of police reform use 'police culture' as an explanatory variable (Chan 1997, Reiner 1992, Barton, 2003). Police culture may continue to exist as a bond which drives resistance to outsiders (Loftus 2009). In an alternative view it is feasible to theorise that the resistance to change shown by some police (particularly within the non-commissioned ranks) may be a symptom of reform fatigue (Brodeur 2007) as a consequence of many years of a constant cycle of change in policy, procedures and management initiatives.

\section{The growing burden of bureaucracy}

From inception, British (and later Australian) policing organisations were strongly hierarchical and paramilitary in structure, drawing on practices used in the British 
military (Geller and Swanger 1995, Bayley 1994). This brought its own sizeable bureaucracy as reports travelled up and down an interminable chain of command. However, since the early 1980s a metamorphosis from 'command and control' to 'managerialism' policing models has spawned a new type of bureaucracy. Vickers and Kouzmin (2001) cautioned on the possible deleterious effects of managerialism within Australian police forces if a too rationalistic approach is taken to policing. They describe the sometimes inappropriate embracing of managerialism by police leaders as faddism, with an undue focus on rationalism which is not in keeping with the complexities of policing (Vickers and Kouzmin 2001).

In examining police managerialism, Reiner (1991) observes that senior police are no longer seen primarily as leaders but as managers, identifying a Chief Officer's main challenges as budgeting, internal communications and growing their organisations, with little reference to leadership per se. Fleming and Rhodes (2004b) note that there are other issues associated with legitimacy and authority when police try to operate on this competitive, quasi-commercial basis, drawing on work by Loader (1999), who contends:

The more the police resort to market imperatives as a means of reconfiguring police-public relations, the more difficult it will be for them to speak and act as ultimate guardians of order and security; to stand above the competitive fray and appeal successfully to other principles and loyalists, to 'traditional' modes of authority and expertise. (Loader 1999, p. 378)

In earlier work, Fleming and Rhodes (2004a) observed that over the past 30 years, police services in Britain and Australia have been in a state of constant reform, shifting from a command and control model to one based on markets and more recently, networks. If these new models of governing structures are found to be deficient, more change will likely follow. Thus a continuous, self-fulfilling cycle of 
change and reform occurs.

Notably, none of these changes have decreased bureaucracy levels. Instead new practices and initiatives have often increased the paperwork burden. For example, the past 20 years have seen the rise of police managerialism with contracting as one of its main tools, but the unintended consequences of contracting may be to reinvent the Bureaucratic State (Fleming and Rhodes 2004b).

In 2007 Britain's then HM Chief Inspector of Constabulary was appointed to undertake a targeted review of British policing, which included the reduction of bureaucracy. The review found bureaucracy to be a major issue, such that an Independent Advocate for Reducing Bureaucracy was later appointed to examine ways in which the paperwork burden could be reduced for police. Jan Berry, appointed to the role in 2008, reported publicly one year later, noting:

A cultural change needs to be embedded into the DNA of the service, so that the level of bureaucracy becomes proportionate to the task. This is not a one-sizefits-all approach, but is instead about giving officers a decision-making framework and the personal skills to respond to the context in which they find themselves. (Berry 2009, p. 7)

Police bureaucracy has also bloomed as a result of rapid diversification of policing into specialist functions and management silos and the splintering of management and command as a consequence. Berry (2009) examined some typical business structures within modern British police forces, finding that meeting and consultation groups and committees exist for dozens of functions raising time, cost and duplication questions.

\section{Bureaucracy and political correctness}

On the subject of bureaucracy and political correctness, Gower-Davies (2012) finds allegations of institutional racism within British police forces (as laid by the 
McPherson Inquiry and other sources) to lack substance and describes how the resulting bureaucratic burdens placed on police forces have impeded their ability to serve the public. This assessment was made in the wake of the conviction of a gang of Muslim men in Rochdale (a large market town in Greater Manchester, England) for the rape of several girls, who were mostly white. It is feared that the sex ring was not sufficiently investigated for several years because of the overwhelming pressures on police to demonstrate racial sensitivity (Gower-Davies, 2011). Alleged police and local authority failings in this matter were considered so serious that a major overhaul of child protection laws and procedures followed (Rochedale-Borough Safeguarding Children 2012).

Gower-Davies (2011) contends that this was a case of reverse institutional racism, whereby concerns of vulnerable white girls from disadvantaged backgrounds regarding ethnic minority suspects were not taken seriously and links this mind-set with the propensity of ' $\ldots$ an over-anxious police leadership to make a fool of itself by adopting policies which are neither operationally nor socially nor ethically sound and proper' (2011, p. 82).

A thorough review of the literature with regard to this key finding failed to find any argument to the contrary. Evidence has now emerged of similar gang related 'grooming' activities in a number of British urban locations over the past two years, so much so that leading British Muslim and child protection organisations launched the Community Alliance Against Sexual Exploitation (CAASE) in May 2013 in an attempt to combat these activities.

In many of these cases, the authorities (including police) have been found wanting in the timeliness and appropriateness of their response (Cockbain 2013), often for fear of 
being seen as racially insensitive. In defence of police, these activities are notoriously difficult to progress for a range of reasons. Nevertheless, the Rochdale case clearly highlights the blight caused when bureaucracy and political correctness collide.

\section{Bureaucracy and the performance target culture}

In the final report on reducing police bureaucracy, Berry (2009) tells the story of a police constable who, upon being assigned a problem housing estate was able to reduce crime over $90 \%$ through a range of community policing strategies, only to be criticised by managers for not meeting arrest targets. Berry (2009) notes that this story reflects the unwanted consequences of the police contemporary performance landscape.

Berry (2009) concedes that performance measurement plays an important role in being accountable, but that it can result in a culture of 'what gets counted gets done' (Berry, 2009, p. 29). This sometimes leads to counterproductive behaviours, in that performance measures may not be a reflection of valuable police work (Berry 2009), as exemplified by the successful policing conducted by the officer referred to earlier.

In Britain there appears to be some awareness of the pitfalls of this target chasing culture in terms of encouraging bureaucracy. In an address to Britain's Association of Chief Police Officers (2010), Home Secretary Theresa May told police that they must no longer chase performance targets, announcing the immediate abolition of the last remaining target, which was to increase public confidence in police. May's comments below can be seen as the most striking attack on police bureaucracy yet by a responsible minister in Britain or Australia: 
I am scrapping the confidence target and the policing pledge with immediate effect ... targets don't fight crime. Targets hinder the fight against crime. ... I couldn't be any clearer about your mission: it isn't a 30point plan; it is to cut crime. No more, and no less. (HM Government, Secretary of State for the Home Department 2010, p. 2)

\section{Educating the public on policing expectations}

Over the past 20 years there has been a significant increase in the level of sophistication in police-public communications. Police now embrace all available methods for communicating with the community, and are becoming adept at choosing individual communication means to target different segments of society, using appropriate social media tools (Hollins and Bacon 2010, Hermann 2009, Clarke 2012). The primary objectives of police in maximising communication with the public appear to be two-fold:

(1) To garner information and intelligence to assist in the fight against crime, thus keeping the community as safe as possible (Feist 1999).

(2) To maintain and enhance the public image of the police, thereby providing assurance about their capabilities to protect the community (Mawby 2001).

Communication methods used in pursuit of the first objective are highly sophisticated, refined and targeted and are vital to the success of modern policing methods. However, whether expending resources on public relations efforts to maintain and polish the image of police (in line with the second objective) can always be justified is open to debate. Mawby (2001), in discussing the rise of public relations activity in promoting the police, notes the exponential rise in budgets and resources allocated by police to this task to feed an insatiable demand by the media. Wright (2012) contends that when the role of police becomes one where they are crafting 
media plans and leveraging new technology that can easily distort or spin facts, then they are not enhancing their reputations through transparency and accountability they are doing exactly the opposite.

Public relations activity by police that is purely aimed at image polishing may include the self-reporting of successes in an at-all-costs portrayal of a dynamic, capable image (Hollins and Bacon 2010). For example, in a 2012 survey the Australian Centre for Independent Journalism study found that $70 \%$ of police stories published in sampled newspapers over five week-days originated from police public relations units (Hollins and Bacon 2010). Chermack (1995) examined how police departments construct public images to ensure favourable media presentation and found that while the media can contribute to police accountability, they are also in the business of providing news that will attract consumers. The strong emphasis placed by police on their public image can be justified as keeping faith with Rowan and Mayne's 1829 principles, by building or at least maintaining public confidence. However, more relevant to this study is how that confidence can be gained.

Myhill and Beak (2008) suggest that the general public are far more pragmatic in their personal assessment of whether or not the police are doing a good job, and are likely to base their views on dealing with the things that matter to their community. Research suggests actual contact with the police is far more crucial to the issue of confidence in the police than public relations campaigns. Gallagher et al. (2001) concluded that citizens' experiences with the police effect their overall assessment of them - the more positive a citizen's recent experience with the police, the more positive the citizen's over-all assessment of them will be (Gallagher et al. 2001). In contrast, Skogan (2006) suggests that negative experiences in publicinitiated encounters have a disproportionately negative impact on confidence, while 
positive experiences in specific encounters are less likely to impact positively on general confidence (the asymmetry theory). Irish research on police marketing and image (Bohan 1987) suggests that, while perceptions of the police can generally be high, support can be patchy and linked to individual areas of grievance. Myhill and Beak (2008) also found that neighbourhood conditions played a significant role in the public's confidence in the police; people who perceived low levels of anti-social behaviour in their neighbourhood had twice the confidence in police of those living with high levels of anti-social behaviour.

Despite significant efforts made by British police forces to maintain and improve their public image some studies suggest that they have slipped steadily in the public's esteem over the past 50 years (Jackson 2010). For example, Jackson (2010) notes that Britain's 1962 Royal Commission on the Police reported that $83 \%$ of those interviewed professed great respect for the police, $16 \%$ said they had mixed feelings and only $1 \%$ said they had little or no respect. Ten years later, Belson (1975) reported on a survey of Londoners which found that $73 \%$ of adults had a lot of respect for the police, $25 \%$ had some respect and $2 \%$ had not much respect.

According to Reiner (2000) the police have dropped markedly in the British public's esteem: 'Where once the police occupied an iconic and identity-bearing status of British life, public confidence is now tentative and brittle ... to be renegotiated case by case' (Reiner 2000, p. 162). To examine the many and complex reasons why the police have slipped somewhat in public esteem is, however, beyond the scope of this study as a multitude of factors about societal change and policepublic dynamics are involved. 


\section{Confidence in the police: a turning point in the debate}

Until recently, public debate about police performance was weighted towards how the police were viewed in terms of accountability and malfeasance (Oliver 1987, Walker 2005). The August 2011 riots in Britain have changed the focus of the debate (Reicher and Stott 2011). For the first time, national debate in Britain post-riots has included major criticism of the police for being 'too soft' in containing the violence that engulfed much of the country (Home Affairs Select Committee, 2012). As might be expected, debate is widespread about the August 2011 riots and the police response (Gorringe and Rosie 2012, Morell et al. 2011).

The British Government quickly established a panel of inquiry into both the causes of the riots and the police response. The Riots, Communities and Victims Panel (RCVP) handed down its interim report in November of that year (2011), stating that: ' ... a lack of confidence in the police response to the riots in London led to further disturbances across England and this had encouraged people to test reactions in other areas' (RCVP 2011, p. 10).

In a formal response, the Metropolitan Police (2011) acknowledged that it was possible that the trouble would not have spread had there been more officers available more quickly. There would appear to be evidence for and against the notion that police were reluctant to confront the rioters. On one hand, the Home Affairs Committee's report, (2011) said flooding the streets with police was what ultimately quelled the disorder, although the same report also accused the police of being 'too soft' in their initial response to the disorder. In support of public allegations of police timidity are the countless eyewitness accounts of the rioting reported in the media of police officers looking on, in some cases metres away, as life was threatened and property stolen or destroyed. As the RCVP (2012, p. 22) notes in its final report: 'It 
seems clear that the spread of rioting was helped both by televised images of police watching people causing damage and looting at will, and by the ability of social media to bring together determined people to act collectively.'

Claims by police that they were simply undermanned are supported by the testimony of mid-ranking police on the streets at the time, later interviewed for a London School of Economics research study (Newburn 2012). The officers claim a shortage of numbers necessitated an approach of safety first to ensure no officer was left isolated or exposed to the mob violence. Some officers believe that these tactics based on manpower shortage were misunderstood by the public as the actions of a timid and confused force (Newburn 2012). Despite some safety justifications, the levels of caution displayed by police, in both policy and practice during the riots can be interpreted as a form of impotence of authority, giving signals of weakness to participants and spectators. This appearance of 'crumbling' authority is worthy of further exploration.

While there has been no shortage of commentary on the police and the 2011 riots, some have widened the debate beyond the usual parameters of police efficacy and what drove the 'anger of the mob'. In a new discourse suggesting a wider collapse of authority, Waiton ( 2012) examines several issues surrounding the motivation of the 'rioters', most of which could, in hindsight be classed as 'looters'. A key point made by Waiton is that, despite there having been a racial catalyst to the riots, the vast majority of participants could not be described as reacting in anger to the police per se (whether on any perceived racial or other injustice) as was the case in prior major disturbances of the 1980s and 1990s. Rather, their ambitions were to commit opportunistic, acquisitive crimes. This leads to the question of how and why such 
numbers of people should feel so emboldened. Waiton (2012 p. 61) made the following observations:

'The destructiveness of the process and the fun of being able to do what you wanted was clearly part of what was taking place. Again this appears to be different from past riots, in terms of the relatively limited expression of anger being shown by those involved. Not in all cases, but regularly and arguably for the most part, there was a kind of childishness and a lack of seriousness about the rioters: it appeared as little more than a game or just an extreme form of 'messing about'.'

Yet whole streets of businesses and homes were burnt and/or severely damaged and hundreds of shops savagely ransacked in several London suburbs. Going further, Waiton contrasts the genuine sense of anger and injustice against police which fuelled earlier British riots of the 1980s to those of 2011. In the latter, the police were not front and centre as the focus of grievance (Murji and Neal, 2011), the wholesale violence and destruction giving more the appearance of individuals encouraged by a wholesale lack of authority from those who can be described as the ruling 'Elites' (Waiton 2012). To clarify, this term is being used here to describe political and community leaders, powerbrokers, senior figures in the Executive (including police leaders) and others who have traditionally wielded great moral and/or legal authority. Some have attributed the erosion of credibility (and thus authority) of the Elites as being of their own making, pointing to the political and banking scandals of mendacity and greed in recent years (Scambler and Scambler 2011). Another explanation proffered, with echoes of strain theory, is that Neo-liberal capitalism has led to a nihilistic consumerist culture (Wall, Moxon 2011) which must be fed by any means, legal or illegal.

Yet others point to a modern socialisation of some young people that has next to no element of personal responsibility, autonomy, self-reliance or respect at its core, 
leading to dependant, narcissistic, vulnerable and 'entitled' cohorts of youth (Waiton 2012 , O’Neill 2011, Furedi 2004). A question worthy of much further research is whether the police have allowed themselves to become the face of this 'crumbling authority' through subtle, almost sub-conscious displays of anxiety about their selfimage, as was glimpsed during the riots?

Certainly, there are signs of discomfort within the Elites on this topic. The initial response of government to police performance during the riots was both noteworthy and highly unusual, in that it offered less than whole-hearted support for the police tactics used (HC Deb 2011). On 11 August 2011 the government convened an emergency parliamentary debate on the riots. In this debate, the Prime Minister praised the bravery of the police but said they had made a major miscalculation when violence first erupted in London. Hansard (HC Deb 2011, p. 1053) records the following remarks by the Prime Minister: 'Police chiefs have been frank with me about why this happened. Initially the police treated the situation too much as a public order issue - rather than essentially one of crime', and later in the same debate:

None of us in the House wants to break with the British model, whereby the public are the police and the police are the public ... but that model has to be refreshed and updated with new tactics, resources and technology, as appropriate, so that it meets new threats. (HC Deb 2011, p. 1105)

More notably in this debate, British Home Secretary May warned that the failure of the police to contain violence jeopardised a core British tradition: 'Policing by consent is the British way, but the police only retain the confidence of the wider community if they are seen to take clear and robust action in the face of open criminality’ (HC Deb 2011, p.1140-1). 
Whether or not police tactics during the riots were too timid, it may be instructive to examine why the police might be keen to be seen as measured in their response to the rioting. Specific and general factors influence this stance. The 2011 riots can be viewed in the context of public debate in the preceding two years alleging police 'heavy-handedness' in the policing of G8 and G20 summits and student protests in London (Gerada and Austin 2010, Heydon 2011). One incident which gave rise to claims of police brutality involved the death of a newspaper vendor following a scuffle with police, as he became involved in a public order situation in central London (Rosie and Gorringe, 2009). These circumstances would suggest that the police are, understandably, highly sensitive to any perceptions of heavy-handedness. But are the police themselves, encouraged by constant public commentary from a range of sources, sometimes confusing police image with police performance?

This brings into focus the constant dilemma of the need to offer 'soft' policing which promotes a warm, friendly public image, yet demonstrate a willingness to police public disorder firmly and with confidence. This study asserts that both approaches constitute re-assurance policing, sending appropriate messages to the public in different circumstances. Innes (2005) concluded that future policing styles need to be able to respond to the diverse demands of the public and that this will require a combination of hard and soft policing.

Worrall (1999) examined in depth the often unseen dichotomy between police image and police efficacy. Factors such as age, race, income and residential location have long figured as variables in the research on public perceptions of police (Gallagher et al. 2001, Skogan 2006, Myhill and Beak 2008) but Worrall (1999) adds further dimensions as variables in the mix: the ability of the police to solve crime and prevent crime. This suggests that the public view the police on at least two separate 
levels: their perceived standing in the community and how well they perform in protecting it from crime.

The British debate now underway on the effectiveness of police in the 2011 riots has significant ramifications for Australian policing. Australian society has yet to be confronted with the type of disorder witnessed in Britain and thus its police remain untested in their response to such an event. Nonetheless, research findings that public perceptions of the police are primarily coloured by their personal experiences and contact with officers (Gallagher et al., 2001) are just as relevant to Australian policing. Research examined in this review suggests that police are more likely to be judged on their actions, rather than words by a pragmatic majority of the public.

\section{Conclusion}

A summative view of the research material suggests that society expects both integrity and effective enforcement from its police - in effect, the idealised 'best of both worlds'. This idealised Police Force would be regarded as both ethical and strong. Policing agencies in both Britain and Australia have generally been successful in delivering this ideal to the public, at least in terms of public image and the reassurance that this brings. However, British policing's continued focus on pursuing Rowan and Mayne's objective of garnering affection may have unintended negative consequences. It is posited that the police, through a preoccupation with self-image, may in fact be on the path to tarnishing their standing with the public. In Britain at least, it seems likely that the public at large have more pragmatic and personal expectations about protection of life and property and maintenance of good order. The British riots of 2011 and their aftermath have thrown this issue into sharp focus. 
It is posited that in a society where discipline of self and community through formal or informal control is not as prevalent as in times past, the police are never likely to be looked on with affection, as envisaged by Rowan and Mayne 180 years ago. It is proposed that an updated, more realistic view of Rowan and Mayne's principles be adopted and brought into the public debate, with more emphasis on respect rather than affection and a renewed focus on protection of the community.

Police in Britain and Australia must strike a careful balance between maintaining trust and respect of the community as an approachable, ethical and communicative entity and providing firm, confident policing, unshackled by fears of being accused by some as being heavy-handed at times. Democratic policing is not and has never been an activity which brings huge popularity to its executors. It can perhaps be better described as a battle to provide assurance to the public - by deeds rather than words - that not only will their rights be protected, but their life and property as well. 


\section{References}

Association of Chief Police Officers, 2012. Policing in the UK: A brief guide. UK: ACPO.

Australian Institute of Criminology, 2012. Police and law enforcement agencies [online]. Available from:

http://www.aic.gov.au/criminal_justice_system/policing/auspol.aspx.

Barton, H., 2003. Understanding occupational (sub) culture - a precursor for reform: the case of the police service in England and Wales. The International Journal of Public Sector Management, 16 (4/5), 346-359.

Batts, A., Smoot, S. and Scrivner, E., 2012. Police leadership challenges in a changing world. New Perspectives in Policing. Harvard Kennedy School. July 2012. USA.

Bayley, D., 1994. Its accountability stupid! In: K. Bryett and C. Lewis, eds. Unpeeling tradition: contemporary policing. South Melbourne, Australia: CAPSM, Macmillan Education, 61.

Bayley, D., and Nixon, C., 2010. The changing police environment, 1985-2008. New Perspectives in Policing Bulletin. Washington, D.C.: U.S. Department of Justice, National Institute of Justice. NCJ 230576. USA, 12.

Beetham, D., 1991. The legitimation of power. Basingstoke, UK: Palgrave Macmillan, 16-30.

Berry, J., 2009. Reducing bureaucracy in policing, final report to ACPO. UK: Home Office, 7-30.

Belson, W., 1975. The public and the police: an extended summary of the aims, methods, and findings of a three-part enquiry into the relations between the London public and its Metropolitan Police Force. London and New York, UK: Harper \& Row.

Bird, G., 1992. The times they are a changing: policing multicultural Australia. In: P. Moir, and H. Eijkman (eds) Policing Australia: old issues, new perspectives. Melbourne, Australia: Macmillan, 352-83.

Bohan, P., 1997. Law enforcement marketing: perceptions of a police force. Irish Marketing Review, 2, 72-86. 
Brodeur, J., 2007. Reform fatigue and the impact of 9/11 on Canadian policing. Director of the International Centre of Comparative Criminology, University of Montreal. Paper to International seminar Explaining majors shifts in policing, an international perspective. 28/29 June 2007. Grenoble, France, 14.

Cameron 2011, p. 1105

Chan, J., 1997. Changing police culture: policing in a multicultural society. Cambridge, UK: Cambridge University Press.

Chermak, S., 1995 Image control: how police affect the presentation of crime news. American Journal of Police, 14 (2), 21-43.

Clarke, C., 2012. Strathclyde police tells more than 130 cops to tweet from the beat. The Firm: Scotland's Independent Law Journal [online]. Available at: http://www.firmmagazine.com

Clarke, R., and Knake, R., 2010. Cyber war: the next threat to national security and what to do about it. New York: HarperCollins, 34-62.

Cockbain, E., 2013. Grooming and the 'Asian sex gang predator': the construction of a racial crime threat. Race Class, April-June 2013 vol. 54 no. 4 22-32.

Cope, S., Leishman, F., and Starie, P., 1997. Globalisation, new public management and the enabling state: futures of police management. International Journal of Public Sector Management, 10 (6), 444-450.

Critchley, T., 1967. A history of police in England and Wales 900-1966. London, UK: Constable.

Critchley, T., 1977. Peel, Rowan and Mayne: The British model of urban police as cited in P.J. Stead, eds (1997) Pioneers in policing. Maidenhead, UK: McGraw-Hill.

Davies, A., and Thomas, R., 2003. Talking COP; discourses of change and police identities. Public Administration, 81 (4) 681-99.

Enders, M., 2001. Introduction: Australian policing in context. In: M. Enders ed., Policing the lucky country. Sydney, Australia: Hawkins Press, 2-3.

Etter, B., 1993. Future directions of policing in Australia, in The Australian Police Journal. March, Australia. pp 43-54.

Feist, A., 1999. The effective use of the media in serious crime investigations. Policing and reducing crime unit paper 120. London, UK: Home Office, 6. 
Fleming, J., and Grabosky, P., 2009. Managing the Demand for Police Services, or How to Control an Insatiable Appetite. Policing (2009) 3 (3): 281-291. August 12, 2009.

Fleming, J., and Lafferty, G., 2000. New management techniques and restructuring in police organisations, policing. International Journal of Police Strategy and Management, 23 (2), 154-168.

Fleming, J., and Rhodes, R., 2004. Networks: the unholy trinity and the police. Paper presented to the 54th Political Science Association Conference at Lincoln University, Australia, April 5-8. Australian \& New Zealand Journal of Criminology August 2005 vol. 38 no. 2 192-205.

Fleming, J., and Rhodes, R., 2004. It's situational: the dilemmas of police governance in the 21st century. Refereed paper presented to the Australasian Political Studies Association Conference University of Adelaide, Australia, 29 September - 1 October 2004. Retrieved from http://www.adelaide.edu.au/apsa/docs_papers/Pub\%20Pol/Fleming\%20\%20R hodes.pdf.

Furedi, F., 2004. Therapy Culture: Cultivating Vulnerability in an Uncertain Age. London, Routledge.

Gallagher, 2001 (Delete if this should have been Gallagher et al. 2001)

Gallagher, C., Maguire, E., Mastrofski, S., and Reisig, M. 2001. The public image of the police. Final report to The International Association of Chiefs of Police. Virginia, USA: The Administration of Justice Program George Mason University, 1.

Geller, W., and G. Swanger., 1995. Managing innovation in policing. Police Executive Research Forum. Washington, D.C., USA.

Gerada, C., and Austin, H., 2010. The policing of peaceful student demonstrators in London was heavy-handed and disproportional from the outset - and it got worse as the day proceeded. British Politics and Policy at LSE (13 Dec 2010). UK.

Gilmore, M., Electing Police and Crime Commissioners:The Challenges and Opportunities of the New Role. The RUSI Journal, 157:5, 6-11. October 2012. http://dx.doi.org/10.1080/03071847.2012.733093. Accessed 1 June 2013. 
Gorringe, H., and Rosie, M., 2012. King mob: perceptions, prescriptions and presumptions about the policing of England's riots. Sociological Research Online [online]. Available at: http://socresonline.org.uk/16/4/17.html

Gower-Davies, J., 2012. Mind-forg'd manacles: murder, Macpherson and the (Metropolitan) Police. Institute for the Study of Civil Society (Civitas), 76-82. Halpern, D., 2010. The Hidden Wealth of Nations. Cambridge, Polity Press. HC Deb. (2011) Col 1053-11141. Available at: www.publications.parliament.uk/pa/cm201011/cmhansrd.

Heydon, J., 2011. The baton \& the camera: The death of Ian Tomlinson and the collapse of surveillance perspective. California. USA: McMaster University.

Hermann, P., 2009. Baltimore police twitter a shooting. Baltimore Sun, 20 March, available online: weblogs.baltimoresun.com/news/crime/blog/2009/03/Baltimore.

Hollins, N., and Bacon, W., 2010. Spinning the media: When PR really means police relations. Australian College of Independent Journalism, Sydney, Australia.

HM Government. Secretary of State for the Home Department, 2010. Theresa May's speech to the National Policing Conference. Home Office. 29 June 2010 p.2. Available at: www.homeoffice.gov.uk/media-centre/speeches/theresa-may-spNPC.

House of Commons Home Affairs Select Committee, 2012, Policing Large Scale Disorder: Lessons from the disturbances of August $2011.16^{\text {th }}$ Report of Session. UK.

Innes, M., 2005. Why 'soft' policing is hard. Journal of Community \& Applied Social Psychology. .Special Issue: Community Policing. Volume 15, Issue 3, pages 156-169, May/June 2005.

Innes, M., Roberts, C., Lowe T., and Abbott, L., 2007. Hearts and minds and eyes and ears: reducing radicalisation risks through reassurance oriented policing. Cardiff University UK, 9.

Jackson, J., 2010. Trust and confidence in policing: A British perspective. Presentation to JUSTIS Conference, London School of Economics, 23-55.

Jackson, J., Bradford, B., Hough, M., and Murray, K., 2012. Compliance with the law and policing by consent: notes on police and legal legitimacy. In: A. 
Crawford, and A. Hucklesby eds. Legitimacy and compliance in criminal justice. Routledge, 5-6.

Jinks, B., 1990. Managing in police reform. Directions in Government, Vol 4, 26-28, 30.

Jones, T., Newburn, T., and Smith, D., 1996. Policing and the idea of democracy. British Journal of Criminology, 1996 - CCJS.

Loader, I., 1999. Consumer culture and the commodification of policing and security. Sociology, soc.sagepub.com, 378.

Loftus, B., 2009. Police occupational culture: classic themes, altered times. Policing and Society: An International Journal of Research and Policy, 20 (1), 4-20.

Marenin O., ed.,1996. Policing change, changing police: international perspectives.

New York, NY: Garland Publishing, Inc. 10003-3304. Available at: https://www.ncjrs.gov/App/abstractdb/AbstractDBDetails.aspx?id=174031

Mawby R., 2001. Promoting the police? The rise of police image work. Criminal Justice Matters, 43 (1), 1-2.

May, 2011, p.1140-1.

Metropolitan Police, 2011. 4 Days in August, strategic review into the disorder of August 2011 - final report. UK: Metropolitan Police Service, 3.

Morell, G., Scott, S., McNeish, D., and Webster, S., 2011. The August riots in England: understanding the involvement of young people. National Centre for Social Research. Paper prepared for Cabinet. November 2011. UK.

Morgan, R., and Newburn, T., 1997. The future of policing. New York, USA: Oxford University Press, Inc., 225-227.

Moxon, D., 2011. Consumer Culture and the 2011 'Riots' Sociological Research Online, 16 (4) 19<http://www.socresonline.org.uk/16/4/19.html> 10.5153/sro.253930 Nov 2011.

Murji, K. and Neal, S., 2011. Riot: Race and Politics in the 2011 Disorders. Sociological Research Online, 16 (4). http://www.socresonline.org.uk/16/4/24.html. 10.5153/sro.2557. 30 Nov 2011

Myhill, A., and Beak, K., 2008. Public confidence in the police. Research, analysis and information (RAI). UK: National Policing Improvement Agency, 1-7.

Newburn, T., 2012. Reading the riots. Research Study, London School of Economics. Conducted with and published by the Guardian newspaper. London, UK. 
O'Brien, S., 1972. The making of a London policeman. International Journal of Offender Therapy and Comparative Criminology, 16 (3), 272-277.

Oliver, I., 1987. Police governance and accountability. NY, USA: Sheridan House Inc.

O’Neill, B., 2011. These rioters are not 'Thatcher's offspring'. http://www.spikedonline.com/index.php/site/article/10989/. 15 August 2011.

Palmer, M., 1995. The likely environment in the year 2000 and beyond. In: Police Leadership in Australasia. Sydney, Australia: Eds. B Etter and M. Palmer. The Federation Press, 3.

Patton, A., 1992. The endless cycle of abuse: why 42 U.S.C. 1983 is ineffective in deterring police brutality. Hastings Law Journal, 44, 753.

Prenzler, T., and Ransley, J., eds., 2002. Police reform: building integrity. Leichhardt, NSW, Australia: Hawkins Press.

Reicher, S., \& Stott, C., 2011. Mad mobs and Englishmen? Myths and realities of the 2011 'riots'. London, UK: Constable Robinson.

Reiner, R., 1991. Chief Constable: bobbies bosses or bureaucrats. UK: Oxford University Press, 227, 228.

Reiner, R., 1992. The politics of the police. 2nd ed. London, UK: Harvester Wheatsheaf.

Reiner, R., 1993. Police accountability, principles patterns and practices. In: R. Reiner, and S. Spencer, eds. Accountable policing: effectiveness empowerment and equity. London, UK: Institute for Public Policy Research, 1096.

Reiner, R., 2000. The politics of the police. (Updated). UK: Oxford University Press, 162.

Reith, C., 1956. A new study of police history. London, UK: Oliver and Boyd, 265288.

Riots, Communities and Victims Panel (RCVP), 2011. Five days in August. Interim Report. London, UK.

Riots, Communities and Victims Panel (RCVP), 2012. After the Riots. Final Report. London, UK.

Rochedale Borough Safeguarding Children Board, 2012. Review of multi-agency responses to the sexual exploitation of children. UK: Rochedale Borough Council. 
Rogers, C. and Gravelle, J., 2012. UK Policing and Change: Reflections for Policing Worldwide. Review of European Studies Vol. 4, No. 1; March 2012.

Rogers, C., \& Martin, H., 2007. Managing Customer Demand. Policing Today, 14(3), 33-34.

Report of the findings of The Royal Commission on the Police, 1962. UK: Home Office, 103.

Rosie, M., and Gorringe, H., 2009. What a difference a death makes. Sociological Research Online, 14 (5).

Ryan, P., 1996. Reform of the New South Wales Police Service - Phase One. Document prepared for Paul Whelan, Minister for Police, 19 November 1996. Australia, 1-26. New South Wales Police Service.

Scambler, G. and Scambler, A., 2011. Underlying the Riots: The Invisible Politics of Class. Sociological Research Online 16 (4) 25. http://www.socresonline.org.uk/16/4/25.html.

Scarman, Lord, 1986. The Scarman Report: The Brixton Disorders 10-12 April 1981.

Middlesex, UK: Penguin Books.

Senior, H., 1997. Constabulary: The rise of police institutions in Britain the Commonwealth and the United States. Toronto, Canada: Dundern Press, 114.

Sheehy, Sir Patrick (Chair), 1993. Inquiry into police responsibilities and rewards. London, UK: HMSO.

Sklansky, D.A., 2011. The persistent pull of police professionalism. New Perspectives in Policing Bulletin. U.S. Department of Justice, National Institute of Justice. NCJ 232676. Washington, D.C.

Skogan W., 2006. Asymmetry in the impact of encounters with police. Policing \& Society, 16 (2), 99-126.

Stone, C., and J. Travis., 2011. Toward a new professionalism in policing. New Perspectives in Policing Bulletin. Washington, D.C.: U.S. Department of Justice, National Institute of Justice. NCJ 232359. USA.

Terpstra, J. and Trommel, W., 2009. Police, Managerialization and Presentational Strategies. Policing: An International Journal of Police Strategies $\backslash \&$ Management, Volume 32, no. 1, p128-143.

Tyler, T., and Fagan, J., 2008. Legitimacy and Cooperation: Why do people help the police fight crime in their communities? Ohio State Journal of Criminal Law, 6, 231. http://papers.ssrn.com/sol3/papers.cfm?abstract_id=887737. 
Uildirks, N., Van Reenen, P., 2004. Policing post-communist societies: police-public violence, democratic policing, and human rights. Human Rights Quarterly 26 (2), 20547-552.

Vickers, M., and Kouzmin, A., 2001. New managerialism and Australian police organizations: a cautionary research note. International Journal of Public Sector Management, 14 (1), 7-26.

Waiton, S., 2012. Wellfare Culture, The English Riots And The Collapse Of Authority. Scottish Affairs, no. 77.

Walker, S., 2005. The new world of police accountability. California, USA: Sage publications.

Walker, D., and Richards, M., 1996. A service under change: current issues in policing England and Wales. Police Studies, 19 (1), 53.

Wall, W., 2011. Tottenham and Beyond: Neoliberal Riots and the Possibility of Politics. Irish Left Review. http://www.irishleftreview.org/2011/08/10/tottenham-neoliberal-riotspossibility-politics/> Accessed 11 June 2013.

Williams, E., and Harris, J., 2008. Scotland Yard. Beginnings and principles of British thought. Harding University. Arkansas, USA: Searcy, 5-28.

Woodcock, J., 1991. Overturning police culture. Policing, 7, 172-82.

Worrall, J., 1999. Public perceptions of police efficacy and image: the 'fuzziness' of support for the police. American Journal of Criminal Justice, 24 (1).

Wright, J., 2012. Police learn propaganda tactics at internet conference [online]. Before its News, 13 September 13. Available at: http://beforeitsnews.com/alternative/2012/09/police-learn-propaganda-tacticsat-internet-conference-2466418.html 